\section{Prediction of red cell mass from weight and height: a nomogram}

RICHARD W. PAYNE Department of Haematology, Worcester Royal Infirmary, Worcester WR5 $1 \mathrm{HN}$, UK

The further investigation of suspected polycythaemia in patients with an elevated venous haematocrit is a not infrequent problem in haematological practice. Measurement of the actual red cell mass (ARCM) in such patients is relatively simple, using standard radioisotope dilution techniques (International Committee for Standardisation in Haematology, 1973). Interpretation of results may be less straightforward, particularly when the red cell mass is expressed in relation to total body weight; for although red cell mass is related to total body weight, it is much more closely related to lean body mass (Muldowney, 1957). Interpretation is thus less subject to error when red cell mass is expressed in relation to lean body mass (Muldowney, 1957; Hyde and Jones, 1962; Hume and Goldberg, 1964). Lean body mass is also closely related to height and weight (Hume, 1966).

Thus the above studies have shown that lean body mass is closely related to ( $a$ ) height and weight, and $(b)$ red cell mass; and hence a relationship between height and weight and red cell mass can be inferred.

Calculations based on the above data of Hume (1966) and Hume and Goldberg (1964) have been utilised to produce a nomogram which allows the expected normal red cell mass (ENRCM) to be predicted directly from height and weight in males and in females (Figure).

This nomogram facilitates the further investigation of patients with an elevated haematocrit, since prediction of the ENRCM is very simple. Subsequent comparison of the predicted value

Received for publication 20 March 1978



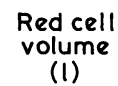

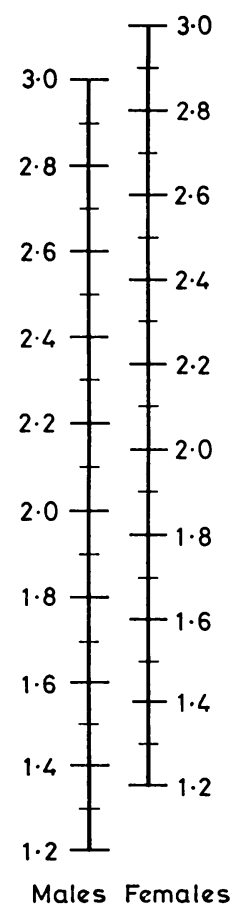

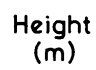

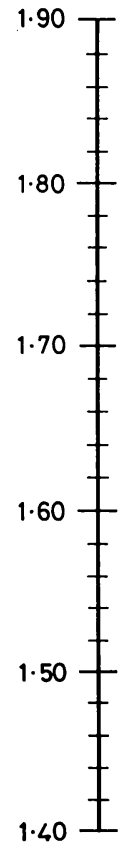

Figure Nomogram for prediction of expected normal red cell mass (ENRCM) from height and weight in males and females. 
with the patient's ARCM allows both the differentiation of 'true' from 'relative' polycythaemia and also the estimation of 'excess' red cell mass in true polycythaemia (Wetherley-Mein, 1974). It has been found to be simple to use and valuable in clinical practice; some examples are given in the Table.

Table Comparison of results of expected normal red cell mass (ENRCM) and actual red cell mass (ARCM) in true and relative polycythaemia

\begin{tabular}{lcccc}
\hline Haematocrit (1/1) & 0.57 & 0.52 & 0.59 & 0.53 \\
Sex & $\mathrm{M}$ & $\mathrm{F}$ & $\mathrm{M}$ & $\mathrm{F}$ \\
Height (m) & 1.64 & 1.59 & 1.59 & 1.50 \\
Weight (kg) & 83.1 & 66.5 & 66.6 & 40.6 \\
ENRCM (1) & 2.05 & 1.65 & 1.75 & 1.21 \\
ARCM & 2.13 & 2.01 & 3.29 & 2.79 \\
Excess RCM & 0.08 & 0.36 & 1.54 & 1.58 \\
& Relative & Primary \\
Diagnosis & polycythaemia & \multicolumn{2}{c}{ polycythaemia } \\
& (due to reduced & (with excess red \\
& plasma volume) & cell mass) \\
& & &
\end{tabular}

My thanks are due to Dr A. P. Kenny for mathematical assistance.

\section{References}

Hume, R. (1966). Prediction of lean body mass from height and weight. Journal of Clinical Pathology, 19, 389-391.

Hume, R., and Goldberg, A. (1964). Actual and predicted-normal red-cell and plasma volumes in primary and secondary polycythaemia. Clinical Science, 26, 499-508.

Hyde, R. D., and Jones, N. F. (1962). Red-cell volume and total body water. British Journal of Haematology, 8, 283-289.

International Committee for Standardisation in Haematology (1973). Standard techniques for the measurement of red-cell and plasma volume. British Journal of Haematology, 25, 801-814.

Muldowney, F. P. (1957). The relationship of total red cell mass to lean body máss in man. Clinical Science, 16, 163-169.

Wetherley-Mein, G. (1974). The myeloproliferative disorders. In Blood and its Disorders, edited by R. M. Hardisty and D. J. Weatherall, pp. 1155-1206. Blackwell Scientific Publications, Oxford.

Requests for reprints to: Dr R. W. Payne, Department of Haematology, Worcester Royal Infirmary, Ronkswood Branch, Newtown Road, Worcester WR5 1HW.

\section{Letters to the Editor}

\section{Bacterial contamination of laboratory forms}

It has been suggested that since request forms and positive culture plates are handled simultaneously by the same technician while working at the bench in the microbiology department, these forms should not be forwarded to the wards or the general practitioners because of the potential risk of cross-infection. Therefore, in many microbiology units the original report is filed in the laboratory office and a photocopy is sent to the clinician. To study this hazard we decided to examine the form filed in the laboratory for the presence of pathogens and other contaminants.

Altogether 129 bacteriology, 50 haematology, and 50 chemical pathology request forms were examined for this purpose. The haematology and chemical pathology forms were included to act as controls.
The forms normally rested on the work bench while being completed. But sometimes all of them were put together inside the bench book. The staff were instructed to wash their hands thoroughly before going to the rest room to eat, drink, or even smoke after handling these laboratory forms in order to minimise the possibilities of laboratory-acquired infection.

Forms from the wound swab bench were sampled with serum-coated swabs dipped in nutrient broth (Oxoid CM67) by sweeping method twice in front and thrice on the back from edge to edge. They were inoculated onto blood agar (two plates-Difco 0792-30) and on MacConkey agar (Oxoid CM76); one blood agar plate was incubated aerobically and one anaerobically. Then the swab was placed in nutrient broth and after overnight incubation subculture was made again as above.
The same swabbing technique wạs applied to forms from the faeces bench but blood agar, MacConkey, and desox cholate citrate agar (Colindale Medi8 Preparation Department) were inoculated and the swab was left in Selenite F brotb (Colindale-as above) overnight. After overnight incubation the broth cultures were subcultured, aerobically and anaero. bically, on blood agar, and aerobically of MacConkey agar.

For forms from the TB room a wed calcium alginate swab (Medical Alginat Ltd) was used. After disintegration of the swab in $10 \mathrm{ml}$ of Ringer's solution con taining $1 \%$ sodium hexametaphosphate (British Drug House Chemical Ltd) the glass universal $(4 \times 4$ in) was centrifuged for 15 minutes at $5000 \mathrm{rpm}$. After decant ing the supernatant, the deposit was inoculated into Middlebrook's mediun (Difco 0713) and incubated for one wee $\mathbb{B}$ at $37^{\circ} \mathrm{C}$. Then the whole of this liquid 